\title{
INTERSTITIAL GRANULOMATOUS DERMATITIS INDUCED BY ANTI-TNF: CASE REPORT
}

JADY ELEN DE PONTES (HOSPITAL UNIVERSITÁRIO EVANGÉLICO MACKENZIE, CURITIBA, PR, Brasil), MARILIA BARRETO GAMEIRO SILVA (HOSPITAL UNIVERSITÁRIO EVANGÉLICO MACKENZIE, CURITIBA, PR, Brasil), BÁRBARA STADLER KAHLOW (HOSPITAL UNIVERSITÁRIO EVANGÉLICO MACKENZIE, CURITIBA, PR, Brasil), DEBORAH CRISTYNE COLOMBO (HOSPITAL UNIVERSITÁRIO EVANGÉLICO MACKENZIE, CURITIBA, PR, Brasil), JULIANA DELFINO (HOSPITAL UNIVERSITÁRIO EVANGÉLICO MACKENZIE, CURITIBA, PR, Brasil)

\section{BACKGROUND}

Granulomatous dermatitis is a rare entity, described in 1993 by Ackerman et al. It is more common in women with rheumatoid arthritis (RA), but it has also been described secondary to other autoimmune disease and associated with drugs like antihypertensives, antilipemic, anticonvulsive and antihistamines. Recently, it has been associated to anti-TNF therapy. This entity has a multiform clinical manifestation and the diagnosis relies on histological findings. The treatment of this entity is not well defined: There are reports of corticosteroid use, anti-inflammatory drugs, methotrexate, hydroxychloroquine and others.

Objective: To describe a case of interstitial granulomatous in a patient with RA probably caused by antiTNF treatment.

\section{CASE REPORT}

The patient was male, 56 years old, on treatment for seropositive RA since 2011. It was initially treated with methotrexate but leflunomide was associated due to persistent activity disease. As the disease remained active anti TNF (Adalimumab) was introduced. In June 2016, after three years of adalimumab plus methotrexate use, the patient achieved remission of his articular disease (DAS 28-VHS: 2.2). In July,2016, the patient presented with erythematous papules and plaques in serpiginous pattern, from the right wrist to elbow, with important local soft tissue inflammation. Skin biopsy demonstrated hyperkeratosis, mild acanthosis and rare lymphocytes in exocytosis in the epidermis and lymphohistiocytic infiltrate around vessels and collagen bundles. The diagnosed of interstitial granulomatous dermatitis with arthritis (IGDA) was made. Treatment with topical and oral corticosteroids achieved only partial response. As the articular disease was in remission, the possibility that this rare entity had been caused by anti-TNF treatment was considered. This medication was suspended. One month after suspension complete regression of the lesions was observed. Currently, the patient remains well controlled using just methotrexate.

\section{CONCLUSION}

In a patient with anti-TNF treatment and IGDA lesions, the possibility of a causal relationship should be explored. 